\title{
Producing Opinion and Building the Agenda on TV Discussion Programs during the State of Emergency in Turkey
}

\author{
By Can Ertuna*
}

\begin{abstract}
The most common prime-time program format on mainstream TV news channels in Turkey is discussion programs that tend to last for several hours. This study, conducted in the aftermath of the coup attempt on July 15, 2016, when the country was in a state of emergency, examines the role of these programs in shaping public opinion by analyzing which agenda is being reproduced by media professionals and media experts. By adapting both qualitative and quantitative research tools, this study advances the following conclusions: 1) Journalists working in mainstream news channels and experts invited to programs on these channels are confined to an agenda set by government officials, and discuss issues within the framework set by those officials. 2) Despite the low ratings of such programs, the owners of these media outlets, with little or no bargaining power in the face of official authority following the state of emergency, are obliged to operate within the red lines drawn by government as the only option to securing the longer-term interests of their businesses in other sectors. 3) Under these constraints, some major topics that are in the public interest are either totally ignored or given little coverage.
\end{abstract}

Keywords: Mainstream media, state of emergency, TV discussion programs, agenda setting, framing.

\section{Introduction}

Political developments in Turkey in the last three years not only transformed the lives of its citizens, but also changed the media landscape dramatically. The most significant events in this tumultuous period were the failed coup attempt on July 15, 2016 during which more than 250 people were killed and hundreds were injured, and the state of emergency declared five days later. The state of emergency empowered the government to run the country via emergency decree and was extended seven times on each occasion for a period of three months. It lasted for nearly two years and came to an end on July 17, 2018, a week before Tayyip Erdoğan won sweeping executive powers in presidential elections. A purge conducted in the coup attempt's immediate aftermath targeting those involved later turned into a massive crackdown. The soldiers and those public servants involved in the planning and execution of the attempt from among the followers of US-based cleric Fethullah Gülen, who allegedly masterminded the attempt were arrested immediately. However, with the state of emergency in effect, the purge also targeted left-wing and Kurdish opposition groups in later stages. According to a report, in the first year of the state of emergency, the authorities took legal action against more than 169.000 people and more than 130.000 people were removed

\footnotetext{
*Assistant Professor, Bahçeşehir University, Turkey.
} 
from public sector jobs by emergency decrees ${ }^{1}$.

As witnesses to one of the most dramatic events in modern Turkish history, the public tuned in to TV news channels in order to keep up with the everchanging political agenda as the tanks rolled out onto the streets and a massive purge got underway following the failed attempt. In Turkey, despite the increasing popularity of on-line platforms and social media as news sources, the number one news source is still television according to the 2018 Digital News Report by the Reuters Institute. A study by Balta, Paker and Çelik (2016, p. 9) shows that $65 \%$ of the population in Turkey learned about the July 15 coup attempt from television. Furthermore, the 24-hour news coverage of TV channels in Turkey still has a "spill-over" effect on internet news websites, with both TV stations and the "mainstream" websites owned by the same media groups. These platforms also serve to set the agenda for the following day's newspapers. It is not only news stories, but also opinion pieces are served extensively to the public through these mediums as is elsewhere. Employing expert opinion to give substance to current events news has been one of the mainstays of TV journalism in Turkey, as it has been in many other parts of the world. Furthermore, current affairs and TV panel discussion programs, which are designed to provide audiences with different perspectives on major topics, have been one of the most popular program formats for news channels. These programs, expected to serve as a pseudo-public space where different points of view and rhetoric collide, also serve as a space for the (re)production of the hegemonic rhetoric.

In countries such as Turkey, where the government's grip on the media is tightening each day, agenda-setting is usually expected to be unidirectional, as Iyengar and Simon (1993, p. 367) demonstrate. That is, news coverage (and program content in this case) affects levels of public concern, and not vice versa. However, the extent of the influence exercised by this official agenda-building and the censorship and self-censorship mechanisms employed by major privately held media companies are still worth exploring. In the main, it could further require a more detailed understanding of the rapid changes which have occurred in the media sphere in a country, which has increasingly been undergoing a political shift away from liberal democracy. This paper aims to explore the level of autonomy of media professionals and its main actor(s) in framing issues and in creating the agenda of the TV news discussion programs in the first months following the imposition of emergency rule. The operation of this agenda-building process is also explored in order to understand the degree of self-censorship and/or of government interference at work. After briefly analyzing the media landscape and describing the relationship between the political, economic and journalistic fields in Turkey in the wake of the coup attempt and state of emergency, the article will focus on the production of TV news discussion programs. With insights provided by the professionals producing these programs and other data, this study will demonstrate censorship and auto censorship practices in agenda-building. The article will also show how, despite minor differences and some "pockets of resistance", the mainstream media lines up behind the hegemonic rhetoric of those

${ }^{1}$ BBC Turkish (July 19, 2018). OHAL Sona Erdi: İki Yıllık Sürecin Bilançosu, Retrieved from: https://www.bbc.com/turkce/haberler-turkiye-44799489. 
in power as journalistic ideals are set aside in times of crisis.

\section{Literature Review}

\section{Setting the Agenda, Drawing the Red Lines, Framing the Issue}

Despite the ever-increasing power of alternative news sources available in the social media sphere, traditional mass media coverage is still vital for a "problem" to be considered a public issue (Dearing and Rogers, 1996, p. 2). However, gatekeepers mediate this coverage and not everyone is welcome to participate. In setting the public agenda, media eliminate a significant chunk of topics and carefully pick the small number of issues that (will) come to public attention (McCombs, 1997; Baumgartner \& Jones, 1993). As Raymond Williams argues (2003, p. 45), although television broadened the forms of public argument and discussion compared to earlier media forms, there have been various restrictions placed on the full range of arguments, with the general exclusion of opposition and minority views. Despite the decreasing levels of trust in main news sources and the ever-increasing power of social media and citizen journalism, Iyengar and Simon's argument (1993, p. 367) is still relevant today, and it is still the mass media that possess the power to set the agenda and not the public in general, although social media platforms' influence in empowering ordinary citizens to promote their agenda is growing. Political leaders are active participants in agenda-setting and without any legitimation by the actors in the political field; topics are excluded from the agenda of news outlets (Cobb \& Elder, 1971; Tuchman, 1978; Berkowitz, 1987). As Pierre Bourdieu makes clear the symbolic power of authorities, through their monopoly of legitimate information, to shape the agenda is on a par with that exercised via their possession of the means of economic pressure (1998, p. 69). From this critical perspective, the mainstream media can be regarded as amplifying an agenda that has already been developed, rather than as acting as the "fourth estate." However, despite the very limited role attributed to the media in agenda setting, Gadi Wolfsfeld's approach, which sees the media play a role not in creating "political waves", but in determining the scale and the power of such "waves", is also insightful (Wolfsfeld, 2005, p. 227). Macroscopic and critical approaches have been criticized by researchers studying news ethnography, who argue that, the "differentiated ecology of news provision" should be analyzed more broadly (Cottle, 2000, p. 31). Furthermore, special emphasis has also been placed on understanding the role of non-governmental actors in the agenda-setting process, especially in liberal democracies. For Mathes and Pfetsch (1991, p. 34), apart from events that have an actual news value, it is also the interest/lobby groups that shape the opinion of journalists first and then the agenda itself. However, in countries like Turkey, in which the political actors enhance their hegemony, by consolidating not only executive, but also legislative and jurisdictive power, especially in times of crisis such as in a post-coup period or during emergency rule, the agenda-setting influence of interest groups ceases dramatically. In addition, one can expect to see opposition arguments muted and 
multiplicity ignored in "the newsroom" in those periods.

Agenda-setting theory has also been consolidated with studies of "priming" and "framing" (Weaver, McCombs, \& Shaw, 2004, p. 258). In the case of TV discussion programs, these two research areas reveal not only the hegemony over what will be discussed, but also how things will be discussed. Therefore, the framing of these issues is as critical as the selection of "experts". Nimmo and Combs (1992, p. 20) attribute great importance to experts and claim that they act as the "fifth estate", next to the executive, judiciary and legislative branches as well as the media as the fourth. However, in building the agenda and framing topics, they collaborate with politicians and media professionals, who possess the power to either include or exclude them. Robert Entman (1993, p. 55) defines framing as "selecting some aspects of reality and making them more salient in a text". Therefore, frames are the imprints of power in news texts and they play a major role in the exertion of political power. As such, in this collective act of framing, it is important to examine how one issue is framed as well as whose agenda it is. Stuart Hall (1978, p. 55) argues that the mass media play the role of a consensus builder when mapping the events "into the frameworks of meaning and interpretation", that is, everyone subscribes to a broader, basic framework of argument despite the differences of outlook, disagreement, argument and opposition. Therefore, it is important to identify the power of the government in countries such as Turkey in not only setting the agenda, but also determining the frame(s) in which topics will be discussed. It is not only the selection of topics, but also the framing of issues that is produced in this circuit of consensus-building in times of crisis.

\section{Media-Power Relations and the Ownership of Mainstream News Channels in Turkey}

Unlike newspapers, which have been owned by non-state actors for a very long time, the private ownership of TV channels in Turkey dates back to the early 1990's, more than 20 years after the first nationwide TV broadcasts began. As the state monopoly ended, private TV stations opened within a short period of time, one after another. Just before the millennium, TV news channels also emerged. However, private ownership cannot be considered a guarantee of pluralism. As De Mateo demonstrates (1989, p. 216), even in Spain during the Franco era, 54\% of the press was owned by the private sector. However, tight restrictions in the market allow only those business owners, who are acceptable to the government to publish newspapers. "The game" does not attract business people for short-term gains only. Indeed, they usually invest to shape the political environment of the markets in which they operate (McNair, 2003, p. 78). Such success means longterm financial rewards despite the short-term monetary losses.

The role the media play in contributing to social change increases in parallel to the extent and progress of division among political elites (Schudson, 2002, p. 253). At a time when officials are at odds with each other, the media amplifies these disagreements in unpredictable ways. However, one could argue that the reverse could be the case in a situation where a certain leader, political party, 
faction etc. acquires excessive power. As Tayyip Erdoğan enhanced his position after consecutive election victories and politically motivated large-scale judicial purges, which were later blamed on loyal Gülen-sect-affiliated bureaucrats at different levels of government, his influence and that of the Justice and Development Party also increased in the media. This has been a three-fold process: 1) the taking over of media companies enabling "friendly" capital owners with cheap credit options from state-owned banks to buy news outlets, formerly owned by business people, whom the government considers hostile to their interests. 2) The creation of new media groups/companies owned by loyal businessmen; establishing new TV channels, newspapers, websites etc. 3) control of those that remain via a carrot and stick policy. This entails the application of political and economic pressure on those outlets, which frequently give voice to the opposition and dissidents, and the rewarding of loyal companies with vast amounts of advertising from state-run banks, government-controlled companies etc. An additional benefit is the provision of easy access to government, and military officials, bureaucrats and even prosecutors, who act as the primary sources of news in Turkish mainstream media. Hallin and Mancini (2004, p. 48) argue that the concentration of capital in the hands of a few in the media sector results in increased government control over the media. This analysis applies to Turkey and therefore, media outlets are usually used as bargaining chips not only for businessmen, who are running businesses in different sectors, but also for those in power, who aspire to control the media. Moreover, as a single political actor consolidates his/her power, fewer concessions are made to "persuade" these business owners. In Turkey, by 2016, the five largest media groups (Doğan, Çalık, Doğuş, Ciner, \& Çukurova) were owned by those, who had already invested in various sectors such as energy, mining, finance, construction etc. (Sözeri, 2014, p. 76). A study by Turkish Bianet and German "Reporter Ohne Grenzen" detailed the ownership of Turkish media in April 2016 just before the coup attempt. By that date, there were 2.371 newspapers, 734 radio stations and $108 \mathrm{TV}$ channels in Turkey. However, the study noted that $40 \%$ of the Turkish audience followed outlets owned by only eight different media groups, five of which were listed above.

The three mainstream news channels, analyzed in this study were all owned by different business owners, who also had investments in other sectors. NTV, founded in 1996, the oldest of the three and a pioneer of private 24-hour news channel outlets in Turkey, is owned by the Doğuş Business Group, which also ran businesses in finance, the automotive industry, construction, tourism, and energy sectors as well as restaurant chains both in and outside of Turkey. By 2016, this group owned six other TV channels, various websites, radio stations and magazines. Habertürk TV, established in 2001, was taken over by an investor, Turgay Ciner, in 2007. Ciner Group ran businesses in mining, energy, chemicals, maritime, tourism and trade. Their media branch owned two other TV channels, a national newspaper, a printing company and a production company. CNN Türk, founded by Doğan Media Group and Turner International in 1999, was owned by Turkey's largest media group Doğan Group at the time of the study. Doğan Group was operating in energy, retail, the automotive industry, marketing, tourism, finance 
and real estate as well as TV broadcasting. It also owned a media group, radio stations, websites, printing houses and was one of the two largest newspaper distributors in the country. In March 2018, the owner of the group, Aydın Dogan, who had been severely criticized many times in the past by Erdoğan and was hit by a 2.5 billion dollar tax fine, sold his media assets to another group, Demirören, for a price that was reportedly quite lower than the actual prices according to various commentators. The owner of the Demirören Group was allegedly one half of a leaked telephone conversation with Tayyip Erdoğan, in which he tearfully promised to take measures in relation to a news story published in his paper Milliyet, which Erdoğan, Prime Minister at the time, was immensely critical of. This takeover by the Demirören Group made it the largest in the Turkish media sector $^{2}$.

\section{Methodology}

The study's findings are based on fieldwork conducted in the first months after the declaration of the state of emergency. Although the state of emergency was declared in July 2016, the research period selected was late autumn as October usually marks the beginning of the new broadcast season after the summer break for most of the Turkish TV channels, and by the end of that month, all season-long programs were scheduled and program formats finalized. In order to draw a general picture of the structure of the journalistic field in Turkey during this period, qualitative research methods were also employed in this study, with the research consisting of three main pillars. First, all of the prime-time discussion programs on the three mainstream Turkish news channels, namely; NTV, CNN Türk and Habertürk were analyzed in the two-week period between October 24, 2016 and November 4, 2016. Overall, 27 different programs, lasting some 78 hours over this period were analyzed with regard to the variety of experts invited and their agendas, compared to those of President Erdoğan and Prime Minister Yildirım in the same period. Both are the founders of the AK Party (the Justice and Development Party), which has ruled Turkey since 2002. Erdoğan has been the most influential figure in the party ever since, and Yildırım was the prime minister of that period appointed by Erdoğan. Second, the themes and sub-themes of Erdoğan and Y1ldırım's speeches were classified via content analysis and coded by the author into separate topics. The agendas of the various programs were examined by measuring the time spent on each topic in these discussions. The two clusters of data were then compared to determine similarities and differences. Third, with a view to complementing the quantitative analysis, semi-structured indepth interviews were conducted during the same period with 24 people, including editors, producers, guest coordinators and presenters of these programs as well as TV experts of different backgrounds. However, since many of them asked not to

\footnotetext{
${ }^{2}$ Kadri Gürsel (2018, p. 14), a prominent Turkish journalist, who had served a 11-month prison term during the period, 2016-17, argues that this acquisition marks the end of "mainstream" media in Turkey. Gürsel, who previously had worked for both the Doğan and Demirören media groups asserts that, by orchestrating this takeover, the government had gained full control of the media.
} 
be named, only their positions are mentioned in the article.

This research differs from many classical agenda-setting studies such as the well-known 1972 Chapel Hill study by McCombs and Shaw, in which the emphasis is on measuring the influence of news media on the public agenda by polling a sample of people. Furthermore, emphasis was placed on understanding the extent of political influence over the media's agenda-setting role. In this study, the primary focus is on the testimonies of the media employees interviewed. However, in addition to this, comprehensive research conducted by Kadir Has University about ordinary people's agenda in the same period is also introduced to examine the effects of the media agenda on that of the public. An examination of a previous period would also serve to usefully determine the extent of the transformation in the media sphere. However, since the rating system, used to measure the success and/or impact of TV programs had changed before this study was undertaken, and no other study on a similar topic was available, a comparative approach could not be employed.

\section{Results and Discussion}

\section{The State of the Media in Turkey in the Wake of the Coup Attempt}

The pressure on the media sector, which had been under the influence of the government, as noted above, increased considerably following the coup attempt and during the state of emergency. According to a report by the T24 news website, within the first six months of the state of emergency, 16 TV channels, 24 radio stations, 19 periodicals and 29 publishing houses were shut by statutory decree, only 19 of which were later to be reopened by further decrees. However, it was not only media outlets that were associated with the Gülen movement that were affected; many left-wing and Kurdish outlets were shut as well. In the decree, such media outlets were described as being "associated, or in contact with, terrorist organizations or groups and organizations, which are considered by the National Security Council as acting against the national security of the State". According to a report by the Committee to Protect Journalists, in that period, Turkey accounted for a third of the journalists jailed in the world with at least 81 journalists imprisoned. Journalists faced anti-state charges such as "plotting a coup", "propagandizing for an illegal organization", "being a member of an illegal organization" etc. Further, banning the coverage of specific events has been another restriction on press freedom in Turkey. According to data by the Radio Television Supreme Council of Turkey, in 2016 alone, a broadcasting ban was applied to 40 different events. According to the Turkish Journalists Association, 14 of these bans concerned large-scale events such as social unrest, a terror attack etc. In another report by the same association, more than 10.000 media employees lost their jobs that year due to the closure of their media outlets. 


\section{TV News Discussion Programs on Turkish News Channels}

As noted, according to various studies, TV is still the main source of news for people in Turkey. During the period of this research, its sphere of influence grew even wider. However, despite this, owners do not invest heavily in good quality reporting, but rather try to maximize profit by decreasing newsroom costs. As Jacobs and Townsley $(2011$, p. 5) make clear, in the US, the general trend is for media owners to reduce reporter numbers, which has also resulted in a decreasing number of investigative news stories. A similar trend is evident in Turkey, but one that is more effective, as government pressure on news outlets makes owners reluctant to invest in investigative journalism and high quality journalism. Competition, among the TV news channels ceases and the executive directors of those channels fill airtime with cheaper program formats, one of which is discussion programs. The owners of news channels in Turkey do not consider news media itself to a profitable short-term business investment. The decreasing space for investigative pieces means a widening space of opinion, not necessarily in diversity though, but in volume. The result is an increase in broadcast hours for TV discussion programs, in which experts, or "fast thinkers", as Bourdieu likes to call them (1998, p. 28), discuss and argue about current social and political issues. One program director interviewed on October 25, 2016 said; "Such programs are so cheap. You had already invested in studios, employees etc. The only extra cost would be to cover the travel expenses of a guest you invite from outside (from Istanbul). Other than this, any other program format costs more. You cannot find a four-hour documentary, but you can make people discuss something for four, or even five hours!"

News channels have the highest rating scores in times of crisis. However, on ordinary days, normally, rating scores are on a par with "primetime TV channels", which broadcast TV serials, talent contests, sports, quiz shows etc. Table 1 below shows this difference between October 24, 2016 and November 4, 2016 during the prime time slot $(8-11 \mathrm{PM})$. These scores, which were gathered from ratings companies and from news channels that work with them, are based on the total percentage of viewers, representing people from all different social and economic strata in society.

The data presented in Table 1 show the lower ratings of discussion programs compared to other program formats just as in many different parts of the world and in different media systems. Furthermore, it is understood that these discussion programs rarely affect the news channels' ratings positively. The low cost of these programs is one benefit for the station owners. However, the real stake in the game is to sustain the balance of power with influential actors of the political field, as these programs and the invited experts serve as agenda-building and framing tools because of what is and is not said. Apart from CNN Türk, which had a wider list of participants representing wider proportions of society during the time of the study, NTV and Habertürk discussion programs had lower ratings than their total 
ratings in a day ${ }^{3}$. This means such programs do not contribute positively to the overall performance of the channel. However, as one program director interviewed on October 25, 2016 says, with the selection of guest speakers, these channels "set the very sentences people tend to use the next day". Another program editor from another TV channel interviewed on October 28, 2016 says “... The rating score would be similar to that of Baby TV, but the impact of the rhetoric should be considered. After all, people care about what is being said on news TV".

Table 1. Rating Scores of Discussion Programs and other TV Program Formats

\begin{tabular}{|c|c|c|c|c|c|c|}
\hline & NTV & CNN Türk & Habertürk & $\begin{array}{c}\text { "Prime } \\
\text { Time" } 1 \\
\end{array}$ & $\begin{array}{c}\text { "Prime } \\
\text { Time" } 2\end{array}$ & $\begin{array}{c}\text { "Prime } \\
\text { Time" } 3\end{array}$ \\
\hline 24.10 .2016 & $\begin{array}{c}\text { Discussion Prog. } \\
1 \\
\mathbf{0 . 3 8} \\
\end{array}$ & $\begin{array}{c}\text { Discussion } \\
\text { Prog. } 1 \\
\mathbf{1 . 5 5} \\
\end{array}$ & $\begin{array}{c}\text { Discussion Prog. } \\
1 \\
\mathbf{1 . 1 3} \\
\end{array}$ & $\begin{array}{c}\text { TV Serial } \\
\text { (Show TV) } \\
\mathbf{7 . 9 5} \\
\end{array}$ & $\begin{array}{c}\text { TV Serial } \\
\text { (Atv) } \\
\mathbf{6 . . 9} \\
\end{array}$ & $\begin{array}{c}\text { Talent } \\
\text { Show (Tv 8) } \\
\mathbf{4 . 5 6} \\
\end{array}$ \\
\hline 25.10 .2016 & $\begin{array}{c}\text { Discussion Prog. } \\
1 \\
\mathbf{0 . 5 3} \\
\end{array}$ & $\begin{array}{c}\text { Discussion } \\
\text { Prog. } 1 \\
\mathbf{1 . 7 4} \\
\end{array}$ & $\begin{array}{c}\text { Interview } \\
\mathbf{0 . 7 4}\end{array}$ & $\begin{array}{c}\text { TV Serial } \\
\text { (Atv) } \\
\mathbf{8 . 9 0} \\
\end{array}$ & $\begin{array}{c}\text { TV Serial } \\
(\text { Star Tv) } \\
\mathbf{6 , 7 2} \\
\end{array}$ & $\begin{array}{c}\text { TV Serial } \\
\text { (Kanal D) } \\
\mathbf{4 . 0 5} \\
\end{array}$ \\
\hline 26.10 .2016 & $\begin{array}{c}\text { Discussion } \\
\text { Prog. . } \\
\mathbf{0 . 4 1}\end{array}$ & $\begin{array}{l}\text { Discussion } \\
\text { Prog. } 1 \\
\mathbf{1 . 5 8}\end{array}$ & $\begin{array}{c}\text { Discussion Prog. } \\
2 \\
\mathbf{0 . 6 5}\end{array}$ & $\begin{array}{c}\text { TV Serial } \\
\text { (TRT) } \\
\mathbf{1 1 . 1 9}\end{array}$ & $\begin{array}{c}\text { TV Serial } \\
\text { (Fox TV) } \\
\mathbf{5 . 8 8}\end{array}$ & $\begin{array}{c}\text { TV Serial } \\
\text { (Star TV) } \\
\mathbf{5 . 3 2}\end{array}$ \\
\hline 27.10 .2016 & $\begin{array}{c}\text { Discussion Prog. } \\
3 \\
\mathbf{0 . 4 9} \\
\end{array}$ & $\begin{array}{c}\text { Discussion } \\
\text { Prog. } 2 \\
\mathbf{1 . 6 8} \\
\end{array}$ & $\begin{array}{c}\text { Discussion Prog. } \\
1 \\
\mathbf{0 . 8 9} \\
\end{array}$ & $\begin{array}{c}\text { TV Serial } \\
\text { (Star Tv) } \\
\mathbf{6 . 0 7} \\
\end{array}$ & $\begin{array}{c}\text { TV Serial } \\
\text { (Kanal D) } \\
\mathbf{5 . 7 3} \\
\end{array}$ & $\begin{array}{c}\text { TV Serial } \\
\text { (Show Tv) } \\
\mathbf{4 . 0 6} \\
\end{array}$ \\
\hline 28.10 .2016 & $\begin{array}{c}\text { Discussion Prog. } \\
2 \\
\mathbf{0 . 3 6}\end{array}$ & $\begin{array}{l}\text { Discussion } \\
\text { Prog. } 2 \\
\mathbf{2 . 3 3}\end{array}$ & $\begin{array}{c}\text { Documentary } \\
\mathbf{0 . 4 7}\end{array}$ & $\begin{array}{c}\text { TV Serial } \\
\text { (Kanal D) } \\
\mathbf{7 . 9 7}\end{array}$ & $\begin{array}{c}\text { TV Serial } \\
\text { (Star Tv) } \\
\mathbf{5 . 5 2}\end{array}$ & $\begin{array}{c}\text { Comedy } \\
\text { Prog. (Show } \\
\text { Tv) } \\
\mathbf{4 . 9 9}\end{array}$ \\
\hline 31.10 .2016 & $\begin{array}{c}\text { Discussion Prog. } \\
1 \\
\mathbf{0 . 4 5}\end{array}$ & $\begin{array}{c}\text { Exclusive } \\
\text { Interview } \\
\mathbf{4 . 1 1}\end{array}$ & $\begin{array}{c}\text { Discussion Prog. } \\
1 \\
\mathbf{1 . 0 4}\end{array}$ & $\begin{array}{c}\text { TV Serial } \\
\text { (Show Tv) } \\
\mathbf{8 . 0 9}\end{array}$ & $\begin{array}{l}\text { (TV } \\
\text { Serial } \\
\text { Atv) } \\
\mathbf{7 . 1 6} \\
\end{array}$ & $\begin{array}{c}\text { TV Serial } \\
\text { (StarTv) } \\
\mathbf{4 . 1 7}\end{array}$ \\
\hline 01.11 .2016 & $\begin{array}{c}\text { Discussion Prog. } \\
1 \\
\mathbf{0 . 3 3}\end{array}$ & $\begin{array}{l}\text { Discussion } \\
\text { Prog. } 1 \\
\mathbf{2 . 1 7}\end{array}$ & $\begin{array}{c}\text { Interview } \\
\mathbf{0 . 6 2}\end{array}$ & $\begin{array}{l}\text { Football } \\
\text { match } \\
\text { (TRT) } \\
\mathbf{1 0 . 0 6}\end{array}$ & $\begin{array}{c}\text { TV Serial } \\
\text { (Star Tv) } \\
\mathbf{9 . 3 3}\end{array}$ & $\begin{array}{c}\text { TV Serial } \\
\text { (Atv) } \\
\mathbf{8 . 2 4}\end{array}$ \\
\hline 02.11 .2016 & $\begin{array}{c}\text { Discussion Prog. } \\
2 \\
\mathbf{0 . 5 8} \\
\end{array}$ & $\begin{array}{l}\text { Discussion } \\
\text { Prog. } 2 \\
\mathbf{2 . 4 8} \\
\end{array}$ & $\begin{array}{c}\text { Discussion Prog. } \\
2 \\
\mathbf{0 . 6 8} \\
\end{array}$ & $\begin{array}{c}\text { TV Serial } \\
\text { (TRT) } \\
\mathbf{9 . 5 9} \\
\end{array}$ & $\begin{array}{c}\text { TV Serial } \\
\text { (Fox TV) } \\
\mathbf{6 . 2 1} \\
\end{array}$ & $\begin{array}{c}\text { TV Serial } \\
\text { (Star TV): } \\
\mathbf{5 . 6 8} \\
\end{array}$ \\
\hline 03.11 .2016 & $\begin{array}{c}\text { Documentary } \\
\mathbf{0 . 2 5}\end{array}$ & $\begin{array}{c}\text { Discussion } \\
\text { Prog. } 1 \\
\mathbf{1 . 4 8}\end{array}$ & $\begin{array}{c}\text { Discussion Prog. } \\
1 \\
\mathbf{1 . 1 3}\end{array}$ & $\begin{array}{c}\text { Football } \\
\text { match } \\
\text { (TRT) } \\
\mathbf{1 2 . 2 8}\end{array}$ & $\begin{array}{c}\text { TV Serial } \\
\text { (Kanal D) } \\
\mathbf{6 . 0 8}\end{array}$ & $\begin{array}{c}\text { TV Serial } \\
\text { (Star Tv) } \\
\mathbf{4 . 3 9}\end{array}$ \\
\hline 4.11.2016 & $\begin{array}{c}\text { Discussion Prog. } \\
4 \\
\mathbf{0 . 5 7} \\
\end{array}$ & $\begin{array}{l}\text { Discussion } \\
\text { Prog. } 1 \\
\mathbf{2 . 1 7} \\
\end{array}$ & $\begin{array}{c}\text { Discussion Prog. } \\
1 \\
\mathbf{1 . 1 3} \\
\end{array}$ & $\begin{array}{c}\text { TV Serial } \\
\text { (Kanal D) } \\
\mathbf{6 . 4 8}\end{array}$ & $\begin{array}{c}\text { TV Serial } \\
\text { (Atv) } \\
\mathbf{5 . 3 2}\end{array}$ & $\begin{array}{c}\text { TV Serial } \\
\text { (Star TV) } \\
\mathbf{4 . 9 5} \\
\end{array}$ \\
\hline
\end{tabular}

\section{The Pool of "TV Experts"}

TV discussion programs are not new in Turkey. Similar programs were broadcasted in the late 1980's on public TRT (Turkish Radio Television Corporation - the only TV company then). However, whether on TRT or on the subsequent first private TV channels, the frequency of such programs was usually once or twice a week. But in the period analyzed, between, October 24 and November 4, 2016, that is, over the course of two weeks, 27 different discussion

\footnotetext{
${ }^{3}$ This is another significant indicator as to why there had slightly been more pressure on the CNN Türk newsroom compared to other channels that resulted in the sale of the media group to a progovernment businessman.
} 
programs were broadcasted on these three channels; almost one program per weekday on every channel. In total, 77 different people (journalists, academicians, policy experts, politicians, lawyers, writers etc.) were invited to the various studios and the programs lasted for more than 78 hours.

The guest lists were designed in a way to favor official rhetoric over alternative formats. Among these 77 people, 22 were journalists - the largest group. It should also be noted that all of these journalists worked in mainstream news outlets. Journalists prefer to invite fellow journalists onto their programs because they are believed to be cognizant of the broader picture and the constraints under which they should work (Paletz \& Entman, 1981, p. 20). Thirteen of these journalists were pro-government, six were critical of government policies, while three of them used neutral language on current issues. However, there are also boundaries with respect to criticism of the government. The classical "manufacturing consent" formula applies here: "Critical sources may be avoided not only because of their lesser availability and higher cost of establishing credibility, but also because primary sources may be offended and may even threaten the media using them" (Chomsky and Herman, 1988, p. 22). All of those interviewed for this research, were of the view that the different voices in Turkish society could not all be represented on these programs, although some were - a position supported even by those with allegiances to AKP. One presenter interviewed on October 14, 2016 said: "There are so few people that I can invite. We are revolving around the same 30 or 40 people 4 days a week". Another presenter from a different channel interviewed on October 182016 said: "Since the June 7 parliamentary elections (2015), I could not imagine inviting an HDP (People's Democratic Party - proKurdish political party) member, a program criticizing the government or one in which the military is criticized. It (the guest list) changed $80 \% "$. Finally, a program coordinator from the third news channel interviewed on October 25, 2016 said: "Mainstream news channels are not based on the idea that their primary mission is to fulfill the needs of people to get objective news. They are not mainly concerned with public broadcasting ethics. This is the reality. The lines are drawn by the capital that owns that channel. It is like running any other business. The frame is determined by the status quo. Sometimes it gets narrow, sometimes it gets wider". It was observed that TV producers and presenters considered experts, who previously had appeared on other TV channels, even rival networks to be "safe choices". On Turkish news TV screens, each program looks similar to its counterpart, as the competition between journalists subject to identical pressures homogenized the "cast", just as Bourdieu claimed (1998, p. 23). In the diagram below, the hours dedicated in each channel's panel discussion programs to major topics are shown. Other than two topics ("Operations against FETÖ ${ }^{4}$ and "Cumhuriyet Newspaper arrests") in which Haber Türk and CNN Türk diverge slightly, similar agenda traits can be observed.

\footnotetext{
${ }^{4}$ An acronym for "Fethullah Terrorist Organisation" - a term employed by officials and the mainstream media to encompass all Gülen-linked references.
} 
Figure 1. Hours dedicated to the Discussion of Major Topics between October 24 and November 4, 2016

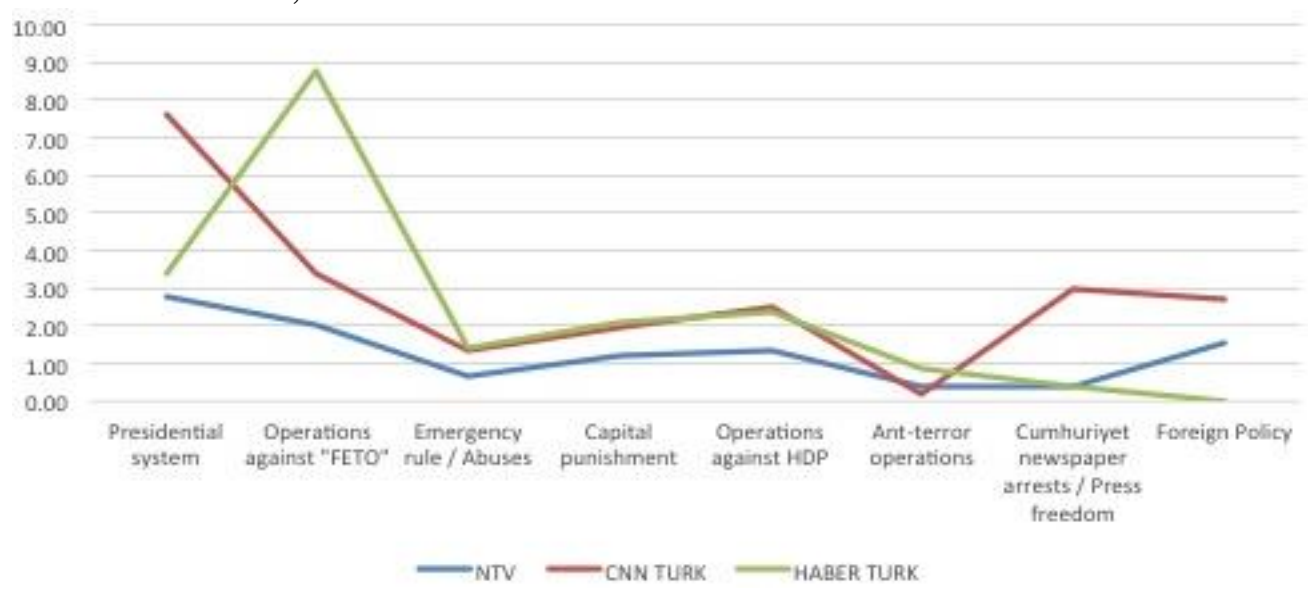

\section{Politicians as Agenda Setters}

During the state of emergency, not only lobby/interest groups, but also most CSOs, some political parties, and factions had difficulty in participating the agenda-setting process. Eight of the ten media employees of different ranks (news/program coordinator, presenter/anchor, editor, producer), who were interviewed for this study claimed that journalists themselves never set the agenda. They pointed to "the President", "Erdoğan", "politicians" and "Ankara" (the Turkish capital used by way of metonymy for "the government") as dictating the agenda to the media, mostly indirectly, thanks to their monopoly in the political field.

A presenter interviewed on October 18, 2016, claimed that they "actually followed the agenda that has already been set by the government". Another presenter interviewed on October 19, 2016, said she could not recall when she was the main actor in setting the agenda of her program. She said, "When I could interview a political leader, I would set an agenda (for other news outlets) however, we usually follow the agenda that has already been set". An editor interviewed on October 20, 2016 claimed that "the agenda setter had been the (then prime minister) Recep Tayyip Erdoğan, since he (the editor) started to work in the media industry". He said: "Erdoğan is an expert in changing the agenda. There sometimes are other topics, but usually Erdoğan is a dominant figure" (in setting the agenda). A producer interviewed on October 24, 2016 said that, it is always preferable for another news outlet (newspaper, TV) to cover a specific story. She said "Then we can stand the criticism from the authorities by pointing our finger to that news outlet as the initiator". However, "the agenda source" cannot be every news outlet, but only some mainstream ones as another producer interviewed on October 22, 2016 put it; "you cannot take a news report from BirGün newspaper (a left-wing opposition newspaper), which could cause trouble for the government and put it into your program's agenda, nobody is that brave". Another producer interviewed on that very same day also said that, for years, the mainstream media had been unwilling to break stories, which had no backing from 
Vol. 6, No. 2 Ertuna: Producing Opinion and Building the Agenda on TV Discussion...

the government. He said, "Topics, which are not backed by strong political will cannot make it to the top of the agenda".

Figure 2. Topics mentioned by President Erdoğan and Prime Minister Yıldırım between, October 24 and November 4, 2016

President \& Prime Minister's Agendas (\%)

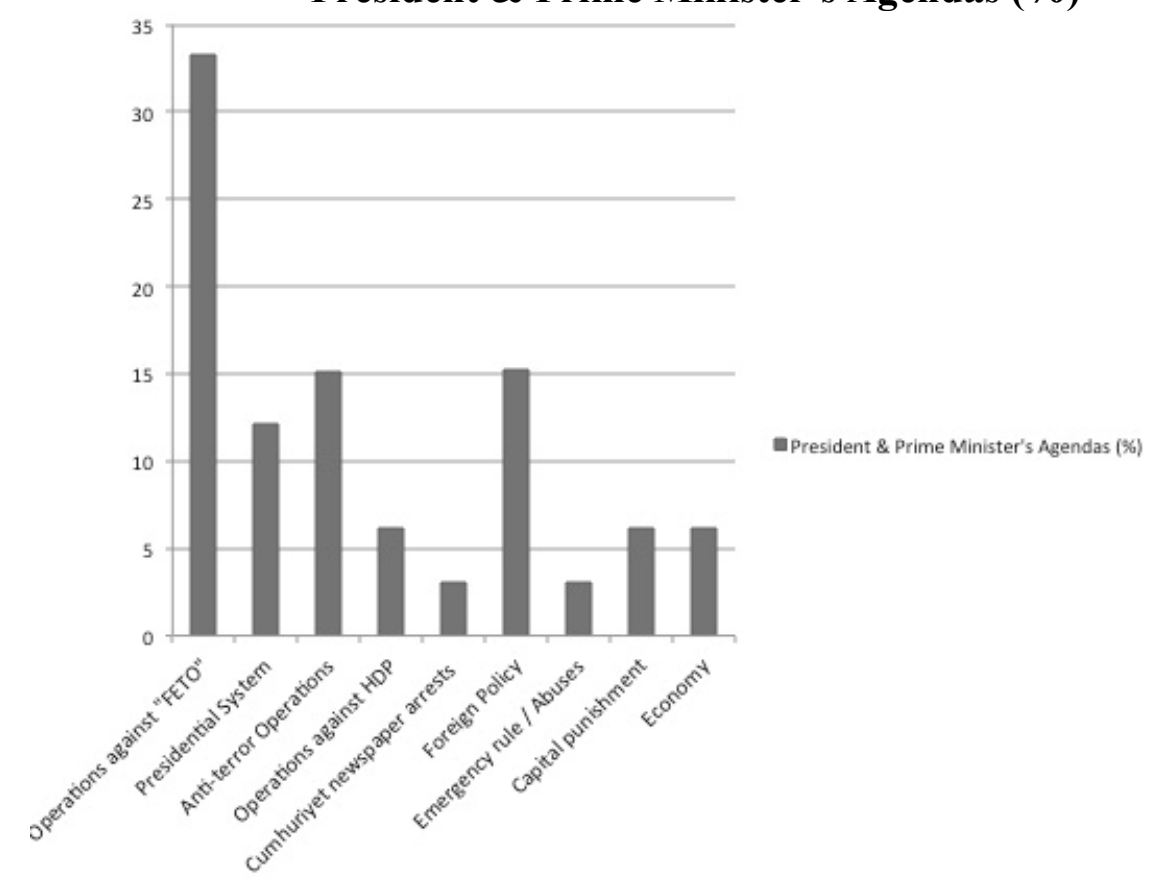

Figure 3. The Agendas of Discussion Programs between October 24 and November 4, 2016

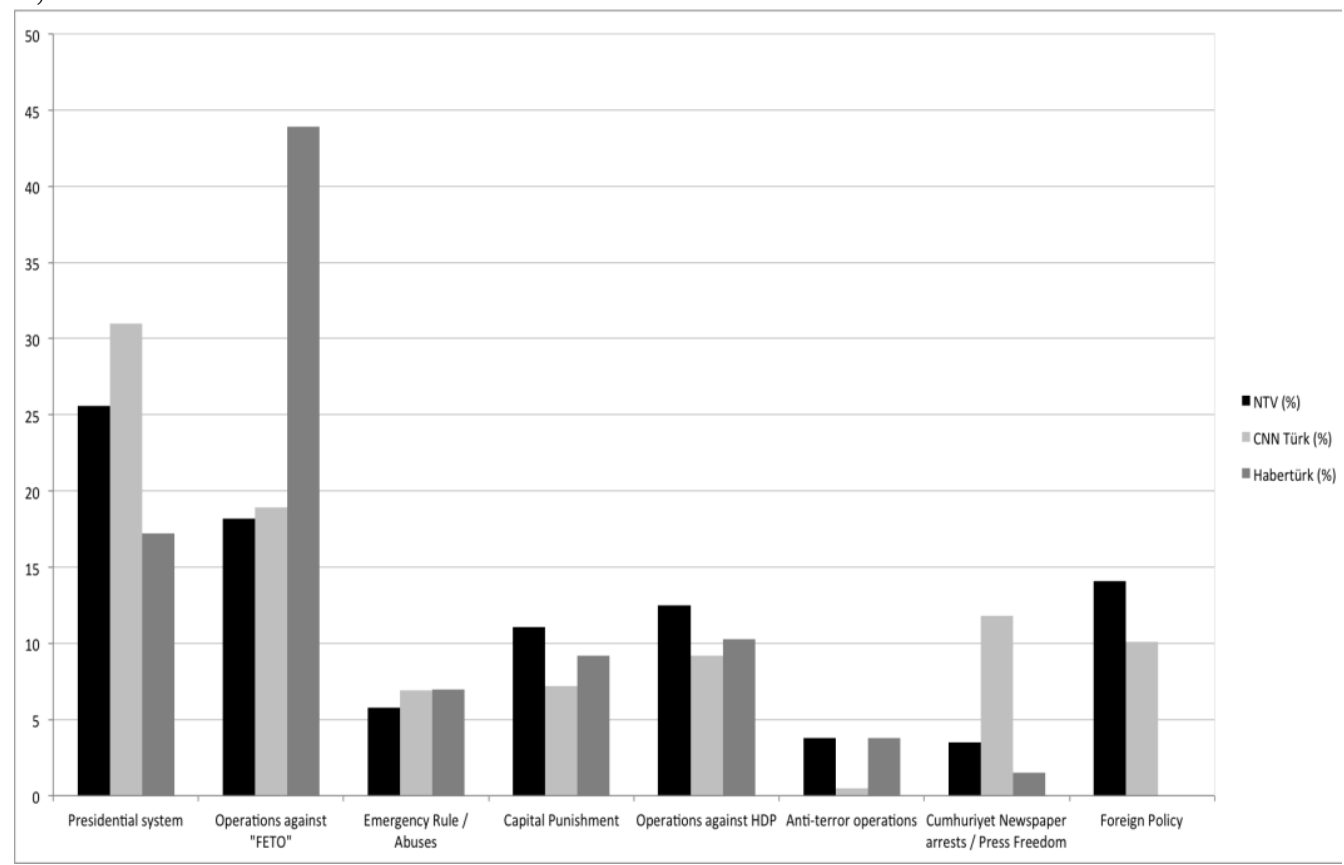


As can be observed from the diagrams above, months after the coup attempt, the crackdown on "FETÖ" and the trials of those, who joined its ranks during the coup attempt, were still the most popular issue on the agenda. The emphasis on this topic in the speeches of President Erdoğan and Prime Minister Yildırım constituted more than $33 \%$ of their agendas combined. Similarly, this was the second most popular topic for NTV and CNN Türk, whereas Habertürk dedicated nearly $44 \%$ of screen time to this discussion. However, in this period, which the main opposition leader, Kemal Kılıçdaroğlu, calls "a civil coup" in the wake of the military attempt, the human rights abuse claims hardly made it onto the news bulletins and discussion programs. During the period of this research alone, the comayors of the city of Diyarbakir, members of pro-Kurdish People's Democratic Party (HDP), Gültan Kışanak and Firat Anl, as well as the co-leaders of the same party Selahattin Demirtaş and Figen Yüksekdağ were taken into custody, later to be arrested. In the same period also, some 1.262 academicians from 77 different universities were dismissed as well as 195 army officers and petty officers. 103 teachers were detained and 193 health officials in the city of Diyarbakir were sacked. However, as noted above, the exposure given to these topics was considerably less than that afforded to the agenda of the President and Prime Minister. It is also worth noting that the subject of capital punishment, which had been very much to the fore at that point in time in the mainstream media, failed to even merit a discussion in parliament. However, emergency decrees, which resulted in the dismissal of tens of thousands of people and hundreds of arrests, were rarely discussed on these TV programs.

It has been asserted that constant alternative media coverage of counter issues makes controversial topics "spill-over" to the mainstream agenda (Mathes and Pfetsch, 1991, p. 55-56). However, during the state of emergency in Turkey, the "spill over" was quite limited, if in evidence at all, and the news channels turned a blind eye to a number of major topics that had a significant impact on the lives of people. In research conducted in December 2016 by Kadir Has University, 1.000 people in 26 different cities in Turkey were asked about "the most important problem in Turkey". According to the study, terror attacks were considered to be the most important problem (35\%). This was followed by "FETÖ" (25.2\%), unemployment $(10.5 \%)$, the high cost of living (9.8\%), human rights abuses (4.8\%), the Kurdish problem (3.5\%), and "the Syria crisis" (the war in neighboring Syria) $(3.3 \%)$. As one can clearly see, economic issues such as unemployment and the high cost of living did not make it onto the agenda of the authorities and the mainstream media. Furthermore, when the subject of terror is usually discussed, it is with a view to framing the Kurdish issue rather than the bombing attacks of ISIS. This then serves as a pretext for the arrests of HDP leaders and MPs.

As the ruling elite picks certain issues via various "priming" methods, the mainstream media quickly adapts to these choices and a closed-circuit agendasetting process begins. A presenter interviewed on October 14, 2016 stated that the agenda of the programs was formulated with reference to (official) announcements in Ankara. She said: "I think ordinary people have no initiative in determining the agenda; I believe their agenda is quite different from ours, however, in these programs those topics are not discussed". One senior journalist who has been 
invited onto discussion programs on these three TV channels, when interviewed on October 20, 2016 said: "It is based on not discussing some issues. They say 'Let's discuss something, but let's not be overtly critical, let's not go into a lot of detail, but does it seem like we're discussing something? O.K. done!' Nearly all of these programs are like this".

\section{Framing the Purge during the State of Emergency}

Ghanem (1997, p. 10) argues that a news headline is one of the essential dimensions in framing an issue. On TV, typically, news topics and headlines are placed within the lower third of the TV screen. TV editors, who are responsible for writing those headlines for the screen, are selected carefully for this task. Bourdieu (2013, p. 138) defines the ultimate censorship as a situation where, "an agent has nothing to say apart from what he is objectively authorized to say: in this case he does not even have to be his own censor because he is, in a way, censored once and for all..." All the program editors interviewed for this research stated that they had been censoring themselves in writing the captions for the screen. However, as circumstances change quickly, the red lines of the authorities also change in a very short time and sometimes it is very hard even for experienced news editors to adapt.

On November 3, 2016, leaders and some of the newly elected MPs of the proKurdish People's Democratic Party (HDP) were detained in a night raid by the police. Most of the mainstream news outlets, including the TV channels analyzed here, used the headline "Terror operation against HDP". One news editor stated that he was warned and instructed (by his superiors) to use this very same headline in conjunction other outlets after he used the headline "operation against HDP". HDP, the third largest political party in the parliament was to be associated with "terror" in the period that followed. In the TV debate programs of NTV and Habertuirk, the common headlines in the following days were "Terror operation against HDP". Only one anchor on CNN Türk chose to use more neutral headlines, such as: "8 HDP MPs arrested" or "Operation against HDP". The other programs presented by different journalists on the same channel however, stuck to the official rhetoric. It should also be noted that, neither a representative from HDP, nor a journalist from Cumhuriyet newspaper, which had been raided by police with some journalists being detained, later to be arrested, were invited to discuss these topics by these TV channels.

When analyzed, it is evident that both the President and the Prime Minister also used a "priming" strategy as an effective extension of agenda-setting in this period. As Iyengar and Simon (1993, p. 368) argue, priming affects "the criteria by which political leaders are judged". We see that both Erdoğan and Prime Minister Y1ldırım succeeded in suppressing issues such as economic problems and human rights abuses by driving the media to more polarizing topics such as the "fight against terror" and the capital punishment draft, which has never been brought in and discussed in the parliament, but has returned to the agenda repeatedly during pre-election campaigns. 


\section{Conclusion}

This article has aimed to contribute to the discussion of agenda-building mechanisms in crisis periods, when governments look to consolidate their power and redefine their relationships with the media. Media companies in Turkey are considered by business groups to be safeguards for investments in other sectors and they have been instrumentalized for the acquisition (or at least the preservation) of political power, with resultant longer-term financial benefits (Adakl1, 2014, p. 18). However, as those in power have gained extraordinary juridical and judicial powers following the state of emergency, media owners lost much of their bargaining power and they became more vulnerable to pressure from officials. Under the state of emergency conditions, the mainstream media in Turkey can be portrayed not only as the subject of the symbolic violence of the hegemonic actors, but also as one of the agents of such violence. The research demonstrates that the mainstream news media have ceased to provide a free and fair platform for even the major political actors of the country to express their opinions. It was also found that the existing political rhetoric had been reproduced in lengthy TV discussion programs by journalists, academics, lawyers etc. This complied with the existing status quo and aligned with political and social positions, which were already heavily polarized. Moreover, all of the respondents (despite their different political and ideological standpoints) claimed that voices of dissent could not be heard on the mainstream media with experts in the media sector arguing that freedom of speech was at its lowest point ever. Edward Said (1996, p. 77) states that in order for someone to be promoted as an "expert", it is necessary to be certified by the proper authorities and to receive instruction in relation to what type of language to use, and what authorities to cite. With respect to Turkish mainstream journalistic practices, avoiding criticism from the authorities has become a primary (and sometimes only) concern for "gatekeepers", if not seeking the approval of authorities even in giving limited voice to opposition every time.

The major differences between the TV channels in relation to agenda-setting and the selection of experts do not occur solely because of the different attitudes held by journalists working on each channel, rather it is a manifestation of the media group owner's overall strategy for dealing with political power. The actors in this journalistic field; namely the editors, producers, presenters, have a very limited role to play. Further, the spillover effect of the agenda of alternative media to mainstream media is not zero, but quite limited. It was observed that this very limited spillover effect of alternative agenda depends on the presenters' or editors' initiative. Therefore, the ever-decreasing number of such journalists in the mainstream media further limits the already narrow scope of journalism. The TV channels analyzed for this research, exhibit minor differences in picking up different topics and guests, and this limited competition has a marginal effect on ratings. These minor differences however, serve to explain the takeover of CNN Türk by a pro-government business group in the months following completion of this research.

Both the data and in-depth interviews clearly demonstrate that agenda-setting 
was strictly within the purview of politicians, and not journalists during the research period. As such, mainstream TV journalism as found on discussion programs within Turkey was (and still is) far from being a part of the "watchdog" journalism idealized in liberal media theories. Furthermore, these discussion programs are designed and presented in such a way that they operate as platforms for the reproduction of existing hegemonic positions through dominant political, ethnic, and religious rhetoric. The lack of pluralism is a threat to democracy and such programs serve to increase the polarization already dividing the society rather than healing it. The transformation for the better in the journalistic field under such circumstances is only possible after a change in the political field, not the reverse. A methodological limitation of this study -measuring audience perception of mainstream agenda-setting and framing efforts- could be addressed in future similar studies. Only then can a fuller picture of the media landscape be drawn.

\section{References}

Adaklı, G. (2014). Medya sermayesi ve ultra-çapraz bütünleşmeler (Media capital and ultracross media ownership). Perspectives: Siyasi analiz ve yorum, Heinrich Böll Stiftung, No: 8: $18-23$.

Aslangül, A. (2016). KONDA araştırması (Konda research). Retrieved from https://bit.ly/365 QCBn.

Balta, E., Paker, M., \& Çelik, A.B. (2016). 15 Temmuz darbe girişimi (July 15 coup attempt). Retrieved from https://bit.ly/33PLD6u.

Baumgartner, F.R. \& Jones, B.D. (1993). Agendas and instability in American politics. Chicago: The University of Chicago Press.

Berkowitz, D. (1987). TV news sources and news channels: A study in agenda building. Journalism Quarterly, 64, 508-513.

Bourdieu, P. (1998). On Television. New York: The New Press.

Bordieu, P. (2013). Language \& symbolic power, John B. Thompson (ed.). Cambridge: Polity Press.

Chomsky, N., \& Herman, E.S. (1988). Manufacturing consent: The political economy of the mass media. New York: Pantheon Books.

Cobb, R.W., \& Elder, C.D. (1971). The politics of agenda building: An alternative perspective for modern democracies. The Journal of Politics, 33(4), 892-915.

Committee to Protect Journalists. (2016). Turkey, a prison for journalists. Retrieved from https://bit.ly/2P8R7ne.

Cottle, S. (2000). New(s) times: Towards a "second wave" of news ethnography. Communications, 25(1), 19-41. doi= https://doi:10.1515/comm.2000.25.1.19.

De Mateo, R. (1989). The evolution of the newspaper industry in Spain (1939-87), European Journal of Communication, 4 (1989), 211- 226.

Dearing, J. W., \& Rogers, E. M. (1996). Agenda setting. London: Sage Publications.

Emergency Decrees no: 675/676 (April, 2018). Retrieved from https://bit.ly/2OPIL5e.

Entman, R.M. (1993). Framing: toward clarification of a fractured paradigm. Journal of Communication, 43(4), 51-58.

Ghanem, S. (1997). Filling in the tapestry: The second level of agenda setting. In Maxwell McCombs, Donald L. Shaw, David Weaver (eds.), Communication and democracy: Exploring the intellectual frontiers in agenda-setting theory (pp. 3-14). New Jersey: Lawrence Erlbaum Associates, Inc. Publishers.

Gürsel, K. (2018). Ben de sizin için üzgünüm (I am sorry for you too). İstanbul: Destek 
Yayınlan.

Hall, S. (1978). The social production of news. In Policing the crisis: Mugging, the state, and law and order (pp. 53-60). London: Macmillan.

Hallin, D., \& Mancini, P. (2004). Comparing media systems: Three models of media and politics. Cambridge: Cambridge University Press.

Iyengar, S.. \& Simon, A. (1993). News Coverage of the Gulf Crisis and Public Opinion: A Study of Agenda-Setting, Priming, and Framing. Communication Research, 20(3), 365383.

Jacobs, R.N, \& Townsley, E. (2011). The space of opinion: Media intellectuals and the public sphere. New York: Oxford University Press.

Mathes, R., \& Pfetsch, B. (1991). The role of the alternative press in the agenda-building process: spill-over effects and media opinion leadership, European Journal of Communication, 6(1991), 33- 62.

McCombs, M. (1997). Building consensus: The news media's agenda-setting roles. Political Communication, 14(4), 433-443.

McCombs, M. E., \&Shaw, D.L (1972). The agenda-setting function of mass media. Public Opinion Quarterly, 36(2), 176-187.

McNair, B. (2003). An Introduction to political communication, London: Routledge.

Media Ownership Monitor (2016). Bianet \& Reporters without Borders, Retrieved from https://bit.ly/2LEHbkP.

Nimmo, D., \& Combs, J.E. (1992). The political pundits. New York: Praeger.

Önderoğlu, E. (2018). 210 years in prison, 3 aggravated lifetime imprisonment for 48 journalists in 3 months. Retrieved from https://bit.ly/2PdA8R2.

P24, Platform for independent journalism, Türkiye'de basın ve ifade özgürlüğü - 18. Freedom of Press and Freedom of Speech in Turkey - 185), (December 7, 2018). Retrieved from: https://bit.ly/34TOFrv.

Paletz, D.L. \& Entman, R.M. (1981). Media, power, politics. New York: Free Press.

Said, E. W. (1996). Representations of the intellectual. New York: Vintage Books.

Reuters Institute (2018). Digital news report 2018- Turkey supplementary report. Retrieved from https://bit.ly/2Lrd2Fh.

Schudson, M. (2002). The News Media as Political Institutions. Annual Review of Political Science, 5, 249-269.

Sözeri, Ceren (2014). Dönüşen medya, değişmeyen sorunlar (Changing media, constant problems). In E. Arsan \& S. Coban (eds.), Medya ve iktidar: Hegemonya, statüko, direniş (pp. 70-85). İstanbul: Evrensel Basım Yayın.

T24, Post July 15 coup attempt analysis, URL (December, 2016). Retrieved from https://bit.ly/2LoO4GE.

Tuchman, G. (1978). Making news: A study in the social construction of reality. New York: Free Press.

Turkish Journalists' Association (2017). Press Release, URL (February, 2017). Retrieved from https://bit.ly/34T7Emb.

Weaver, D., McCombs, M., \& Shaw D.L. (2004). Agenda-setting research: Issues, attributes, and influences. In Linda L. Kaid (ed.), Handbook of political Communication Research (pp. 257-283). New Jersey: Lawrence Erbaum Associates Inc. Publishers.

Williams, R. (2003). Television: Technology and cultural form. London: Routledge.

Wolfsfeld, G. (2005). Political Waves and Democratic Discourse: Terrorism Waves During the Oslo Peace Process, In Lance Bennett \& Robert M. Entman (Eds.), Mediated Politics: Communication in the Future of Democracy, (pp. 226-251). New York: Cambridge University Press. 
